\title{
Rhetorical Entrapment and Normative Enticement: How the UK Turned from Spoiler into Champion of the Cluster Munition Ban*
}

\author{
Margarita H. Petrova \\ Institut Barcelona d'Estudis Internacionals (IBEI)
}

In 2006, Norway launched a stand-alone process to negotiate a ban on cluster munitions. The UK reluctantly joined the process in order to keep it within acceptable bounds. The UK acted as a spoiler in the negotiations. Yet, in the end, it agreed to ban all its cluster munitions and became a champion of the new treaty. Why? I argue that two factors constrained and enticed the UK to go along with the process. First, small states and nongovernmental organizations (NGOs) structured the negotiations in order to disadvantage potential opponents. Second, NGOs also used shaming and praising to define the "desirable" UK policy. Not only did the UK accept a comprehensive ban, but it also started championing it as a result of two mechanisms - "cooperative bargaining" at the end of negotiations that led to a fair compromise and "mobilization of pride" by NGOs praising it for supporting the new norm. Whereas usually the success of weak actors in international negotiations is attributed to the persuasive power of their arguments, I show that strategic action by small states and NGOs may prove crucial in engineering the conditions both for their success and the rhetorical entrapment of stronger actors, such as the UK.

\footnotetext{
* For their valuable feedback, I would like to thank in particular Matthew Evangelista, Stephanie Hofmann, Keith Krause, and Pascal Vennesson. I also thank for the helpful and constructive comments the anonymous reviewers and the editors of ISQ. The article has benefitted also from comments at seminars at Institut Barcelona d'Estudis Internacionals (IBEI) and the Centre on Conflict, Development, and Peacebuilding, Graduate Institute of International and Development Studies, Geneva. I gratefully acknowledge the financial support of a Marie Curie grant from the European Commission and a Max Weber fellowship from the European University Institute, with which research for this paper was undertaken.
} 
In November 2006, the United Kingdom (UK) called a Norwegian initiative for a standalone process to ban cluster munitions "foolhardy" (CMC 2006). Three months later, it joined the same process in an effort to control its outcome. During the ensuing negotiations, the UK drew several "redlines” and vigorously argued for excluding certain types of cluster munitions already in its arsenal from a future prohibition. In the end, though, not only did the UK agree to a strong ban that prohibited all of its cluster munitions, but it also became a champion of the new treaty. Why did a major military power that had recently used cluster munitions decide to suddenly renounce them? Interestingly, the UK considered these weapons "extraordinarily effective" (quote in Rappert 2005:15) just a few years earlier and the government conceded that a ban would impose "serious capability gaps" on its armed forces (UK Government 2007:35). Why could the UK not form a counter-coalition of countries and push for a weaker prohibition or simply withdraw from the process? Neither military and economic interests nor domestic political considerations alone can explain its decision. Nor do constructivist approaches that see similar processes as examples of moral persuasion and the power of discourse (Price 1998; Deitelhoff 2009) fully capture the complexity of the underlying dynamics of preference reformulation.

As a UK diplomat explained, "The process didn't allow it” (personal interview20090526.2-GOV). Organizers strategically structured the negotiations in a way that disadvantaged potential ban opponents. UK officials found themselves "rhetorically entrapped," but also enticed, into participating —and even claiming leadership —in the process. Following Schimmelfennig (2001, 2003) and Krebs and Jackson (2007), I contend that although values matter and argumentation permeates political life, actors 
often adopt new positions not because they are sincerely convinced of their merits, but because they lack "socially sustainable” counterarguments.

Yet a question remains why rhetorically coerced actors do not try to find loopholes in a new treaty, delay its implementation, or simply act as low-key rulefollowers. Why do they sometimes go beyond the minimal requirements, fulfill their obligations ahead of deadlines, or become vocal champions of the new norm? I claim that a shift from rhetorical coercion to cooperative compromising in the last stages of negotiations, coupled with praising states as leaders and "good international citizens," helps create a feeling of ownership of the new norms and entices states to act as norm promoters.

The paper distinguishes between different pathways of "persuasion” that differ from the narrow meaning of Habermasian persuasion as a result of rational argumentation. It illustrates the plausibility of my arguments with a detailed case study of changing UK preferences during the international negotiations for banning cluster munitions.

I begin with an overview of different concepts of persuasion. Next, I illustrate my argument and show how it adds to existing work on rhetorical manipulation. I then highlight the main mechanisms through which the conditions for rhetorical entrapment were set and made to work in the case of the UK. Throughout, I examine and reject alternative hypotheses that emphasize domestic politics, learning processes about the military and economic costs of cluster munitions, or hard bargaining in the negotiations. I conclude with an overview of my argument and its implications for the study of international politics and norm development. 


\section{Pathways to Persuasion and Normative Change}

Recent scholarship investigates the role of different logics of appropriateness, arguing, and bargaining in international negotiations and norm creation (Risse 2000; Müller 2004; Deitelhoff and Müller 2005; Blyth 2007; Krebs and Jackson 2007; Deitelhoff 2009; Morin and Gold 2010; Panke 2010; Risse and Kleine 2010; Bjola and Kornprobst 2011; Johnstone 2011). In particular, authors focusing on negotiations, such as those for the International Criminal Court and the Mine Ban Treaty, present them as examples of the impact of persuasion (Deitelhoff 2009; Rutherford 2003; Ulbert and Risse 2005:40).

However, Payne (2001:46) cautions against attributing causal significance to persuasion based solely on outcomes and practices. Indeed, it proves difficult to disentangle the effects and interaction of bargaining, arguing, and rhetorical action in empirical cases (Deitelhoff and Müller 2005). As a result, theoretical arguments about the role of persuasion face significant limitations when it comes to finding empirical support. They require fine-grained evidence that eludes scholars. ${ }^{1}$ Insufficient attention to the different processes that produce persuasion only compounds this problem

\section{Moral Suasion and the Better Argument}

In genuine persuasion, interlocutors approach each other as equals prepared to change their beliefs and be persuaded by the better argument. The goal is "to reach a reasoned consensus" (Risse 2000:9) with an emphasis on "the content of the arguments and the process of reason” (Crawford 2002:9, 15). In an ideal speech situation, the "logic of

\footnotetext{
${ }^{1}$ I thank Keith Krause for this point.
} 
arguing" excludes "all force... except the force of the better argument... all motives except that of a cooperative search for the truth" (Habermas 1984:25). The criteria about the better argument regard an all-inclusive procedure that achieves consensus (all stakeholders have a say) and the universality of arguments across audiences (Habermas 1984:26; Deitelhoff 2009:45, 53; Hanrieder 2011:400-1). Such a generalized consensus translates into "a synthesis, that all regard as superior to their previous position” (Bellamy 1999:102) and leads to a sincere change in causal or principled beliefs (Risse 2000:9).

However, it proves difficult to show whether persuasion actually operates in realworld politics. Scholars therefore look for institutional conditions that should favor communicative action. They assume that the presence of such conditions implies persuasion (Deitelhoff and Müller 2005; Deitelhoff 2009; Risse and Kleine 2010; Glasius 2008:49-50; Risse 2004). Strategic action, to the extent that scholars address it, resolves only as a first step to make way for communicative action. Weak actors, such as small states and non-governmental organizations (NGOs), act strategically, but given their lack of material power, their success ultimately rests on their arguments' persuasiveness (Risse 1999:536). While such Habermasian-oriented works try to build a strong case for the importance of communicative action in international relations, critics accuse them of displacing the focus from other sources of persuasion and other forms of agreement (Hanrieder 2011; Steffek 2005; Kornprobst 2007, 2014).

\section{Strategic Arguing, Rhetorical Entrapment, and Compromising}

Often, an outcome may look like persuasion but differ from the kind associated with Habermasian theory. When the actors' adopt a strategic, rather than truth-seeking 
orientation, the outcome will reflect a compromise rather than "reasoned consensus." That is, no change in preferences ensues. For example, Finnemore and Sikkink (1998:914) define "persuasion" as "chang[ing] the utility functions of other players to reflect some new normative commitment.” For Checkel (2001:562), argumentative persuasion "involves changing attitudes about cause and effect in the absence of overt coercion." Such persuasion does not require truth-seeking. It comes close to a rationalist understanding of "information updating," but with the difference that a preference change results from interaction.

Rhetorical entrapment stems from a strategic process in which actors do not regard each other as equals and are not open to changing their minds. Public commitment to a principle for instrumental reasons, in the process of argumentative exchange and scrutiny from interlocutors, "locks in” the speaker - they cannot argue against the already accepted principle without appearing inconsistent and losing their credibility. Actors strategically use such concerns and "norm-based arguments in the pursuit of one's self-interest" (Schimmelfennig 2001:63). They seek to persuade, but "are satisfied if the audience and opponents stop opposing their claims (whether or not they are really convinced) and behave accordingly" (Schimmelfennig 2003:206). Thus, "internalization of rules is not necessary” (Schimmelfennig 2003: 197; see also Krebs and Jackson 2007:36).

Additionally, actors can agree on new positions without being persuaded, because they consider the solution acceptable for different reasons, deem the procedure through which it was reached fair, or value a common agreement (Steffek 2005:236-237; Kornprobst 2007:81; Reh 2011; Thomas 2009). Reh (2011) introduces a hybrid category of "inclusive agreement" that combines elements of arguing and bargaining. It resembles "rhetorical action" regarding the mechanisms through which actors reach agreement, but 
differs because they regard each other as equals and seek cooperative solutions - a process similar to "cooperative bargaining" wherein actors share "common goals and values", trust “diffuse reciprocity," and have a preference for consensus (Thomas 2009:347). The resulting compromise strikes participants as fair and takes the form of "a package many of the components of which...[compromisers] would reject if taken in isolation. Though they consider the agreement as the most acceptable to all concerned, each retains his or her own view of what is best” (Bellamy 1999:102).

\section{Authority and Educating}

Scholars often differentiate rhetorical entrapment and compromise from persuasion. But they rarely distinguish Habermasian persuasion from persuasion achieved through mechanisms other than rational reasoning. For example, the authority and social relations enjoyed by argument-makers can play the central role in persuading their interlocutors (Checkel 2001; Kornprobst 2014:195). Indeed, who delivers the message may be equally or more important than the message's content. Speakers with superior experience or moral authority may persuade the audience but the kind of persuasion at work differs from that associated with communicative-action accounts. Rather than exercising free individual judgment, the persuadees transfer their judgment to those they see as more knowledgeable. The relationship between the interlocutors is not one of equality but hierarchy - a process that resembles educating more than it does persuading (Rorty 2000:22). To the extent that NGOs can bestow or question the legitimacy of certain arguments by virtue of holding the high expert or moral ground (Keck and Sikkink 1998), they wield persuasive power in addition to (or irrespective of) the validity of their arguments. 


\section{Emotions and Altercasting}

The persuadee may also respond to emotional appeals (Crawford 2009; Hanrieder 2011) - something the Habermasian framework of rational communicative action ignores (Diez and Steans 2005:135-6) but that performative theories of rhetorical action emphasize (Schimmelfennig 2003:200). Here the relationship to the speaker determines the outcome, but emotional relationships drive the process (e.g., a friend might receive a more favorable hearing than a foe). People may also be persuaded because of the emotions invoked by a message, the carrier of the message, or both. Children or innocent victims prove effective speakers for certain causes when they trigger feelings of responsibility, duty, or guilt among the audience, who are altercast in the roles of responsible and caring individuals (Pratkanis 2000:211). Altercasting captures the process of “projecting an identity, to be assumed by other(s)” (Weinstein and Deutschberger 1963:454). It often works by evoking feelings (of guilt, shame, empathy, or pride) and attaching respective roles to them. As a result of this affective push or pull, actors may assume the roles projected for them. Despite their importance, however, IR scholars have only recently begun to study emotions. $^{2}$

These diverse types of persuasion reflect the complexity of the processes involved, delimit the scope of Habermasian persuasion, and call for careful attention to the mechanisms through which normative change results.

\footnotetext{
2 See Crawford (2000, 2009, 2013), Bleiker and Hutchinson (2008, 2014), Bially Mattern (2011), Sasley (2011), Fierke (2013), Mercer (2013), Jeffrey (2014).
} 


\title{
Argument: Rhetorical Action and Altercasting
}

\author{
Strategic Organization of Negotiations
}

The organization of negotiations plays a critical role in how they unfold. Moving negotiations to a stand-alone process for those favoring the establishment of new norms tilts the balance in favor of norm-proponents, delimits the scope of legitimate arguments, and creates the conditions for rhetorical entrapment of opponents. What matters more than the formal decision-making procedure, is the strategic framing of the negotiations' goals and participant selection. Authors highlight the importance of the change from consensus to majority decision-making for the success of similar processes, especially in the banning of landmines (Coleman 2013; Hubert 2000; Rutherford 2000:113). However, negotiations can be structured in a way to avoid the need for voting at the end - state positions are already channeled to a compromise in the prior negotiation stages.

Here I draw on Riker's work on heresthetics, the art of political manipulation. ${ }^{3}$ Riker (1986:ix) studied how winners in political processes "set up the situation in such a way that other people will want to join them - or will feel forced by circumstances to join them - even without any persuasion”. Although his work focused on rational choice and agenda manipulation or voting procedures in domestic contexts, its broader insights apply to international negotiations. There are several ways leading states of a stand-alone

\footnotetext{
${ }^{3}$ I thank Matthew Evangelista for drawing my attention to Riker’s work. See Evangelista’s (2001) excellent application of heresthetics to the Cold War's end.
} 
negotiation process can shape it in ways that strengthen their own positions and rhetorically “entrap” opponents.

First, leading states set the agenda of negotiations. By choosing to focus on some issue aspects they favor, organizers exclude opponent's points of view. By limiting the circle of participating states to those willing to publicly subscribe to the stated objective of negotiations, they also create the conditions for rhetorical entrapment of "sneaky" opponents. At the same time, if the leading states remain vague about the measures necessary to achieve that objective, they leave room for interpretations that suit the interests of different participants. ${ }^{4}$ Second, leading states set the agenda. When faced with strong opposition and the need to keep up support for negotiations, organizers may prefer to initially discuss relatively uncontroversial issues where agreement is easily achievable. They defer the most divisive issues until later stages. Third, organizers can establish a specific deadline by which the treaty must be completed and present the final deal as a “take-it-or leave-it” package - heresthetic maneuvers aimed at preventing indefinite discussions that could bog negotiations down (Riker 1996:11, 254). Finally, the organizers can attract to the process states whose particpation would widen the spectrum of preferences and shift the median toward the organizers’ position. Through these steps, leaders of the process can increase its following and ensure their own command of it.

\section{Altercasting and Rhetorical Entrapment}

\footnotetext{
${ }^{4}$ Evangelista (2001) identifies as a heresthician's device the ambivalence of statements and their framing in a way to resonate with different interests.
} 
Riker (1986:ix) emphasized that herestherics is an art; "no set of scientific laws that...generate successful strategies" existed. Thus, he provides no clear scope conditions for the success of the aforementioned strategies. However, in international negotiations, they depend on actors' desire to maintain their social status and credibility, and hence, are linked to 'rhetorical entrapment.' Goffman's (1959) work provides social mechanisms through which actors structure a situation and make "rhetorical entrapment" work. I start with these theoretical assumptions, but add new dimensions to "rhetorical entrapment" by looking at a complementary process of altercasting. The concept of altercasting refines Goffman's focus on how an actor's self-representation defines a situation and conditions the responses of others. Altercasting, in addition, looks explicitly at how actors define the roles others should play. It involves "projecting an identity, to be assumed by other(s)...which is congruent with one's own goals" (Weinstein and Deutschberger 1963:454). An actor doesn't simply control impressions of himself, “[h]e takes a direct hand at changing the array of behavioral alternatives available to alter" (Weinstein and Deutschberger 1964:455). ${ }^{5}$

I argue that altercasting incorporates both the familiar "naming and shaming"—or "mobilization of shame” strategy—and what I call "mobilization of pride." "Mobilization of shame” exemplifies "negative altercasting” (Turner, Banas, Rains, Jang, Moore, and Morrison 2010:3) whereby one actor (NGOs) casts a state in the role of a "rogue" outside the community of civilized states or a "duplicitous" state that doesn't live up to its own professed values. To avoid being identified with this undesirable role, the state has to comply with the altercaster's demands. In contrast, "mobilization of pride" represents "positive altercasting." Altercasters use praising to entice states to take on the lead in norm

\footnotetext{
${ }^{5}$ Wendt (1999:326-36) uses the concept to depict social learning and identity (re)construction.
} 
creation, but also to spur reluctant states to follow as commendable members of the international community and solidify their commitment to newly adopted norms. Although both negative and positive altercasting depend on the actors' need for maintaining self-esteem (Schimmelfennig 2003:197; Finnemore and Sikkink 1998:9034), the process of motivating compliance by praise is generally neglected though acknowledged (Finnemore and Sikkink 1998:902). Despite the voluminous work on how NGOs pressure or persuade states, the subtle mechanism through which they cast upon states certain, especially positive, roles to play has received little attention - a gap I try to fill in. ${ }^{6}$

Whereas “naming and shaming” depends on states' rhetorical commitments, positive altercasting can go beyond existing role conceptions and promote the adoption of new ones. Importantly, positive altercasting can make rhetorical entrapment work. When NGOs cast a state in a positive light as a potential leader and that state adopts the role projected for it, it opens itself up for criticisms if it fails to follow the role script. Thus positive altercasting can be a facilitating condition for rhetorical entrapment.

As in heresthetics, it is not clear under what conditions altercasting works. Studies of "rhetorical entrapment” predominantly focus on the domestic and regional levels where the rhetorical endorsement of agreed community norms creates the preconditions for entrapment. Krebs and Jackson (2007:56) argue that rhetorical coercion works internationally through the pressure wielded in the domestic setting where community ties are densest. In contrast, I focus on the international level where countries share a thin understanding of common values. I highlight the preconditions for and the dynamic nature

\footnotetext{
${ }^{6}$ Even a volume on role theory in IR mentions altercasting only in passing (Harnisch, Frank, and Maull 2011:13).
} 
of rhetorical entrapment during norm development. In this case, figuratively speaking, actors do not fall into the "trap" once they publicly commit to existing norms. Instead, the argumentative loop gradually tightens as the contours of new norms are negotiated.

Most states aspire to be perceived as "good international citizens," but some are more vulnerable to altercasting than others. Prior commitment to certain norms makes states more receptive to appeals for leadership on related norms. In addition, Gurowitz (2006) argues that states uncertain about their belonging to and status in international society are more likely to respond to pressure to adopt international norms. States relegated to a secondary status or occupying peripheral positions in the international or a regional system can be expected to aspire to improve their status (unless they find alternative status markers). ${ }^{7}$ Altercasting matters in these cases since status is relational and depends on the perceptions of others in international society. ${ }^{8}$ Especially for states that cannot claim status based on material capabilities or exhibit a mismatch between strong material and weak normative claims to status, ${ }^{9}$ ideational resources, such as active diplomacy and belonging to a vanguard group of states working for the creation of new international norms, can be a source of self-esteem and status. Hence, status deficit or status loss can make altercasting effective.

Who the altercasters are also matters. Importantly, NGOs and other states (not necessarily only high-status great powers) can confer status, ${ }^{10}$ including through altercasting states as leaders on the international arena.

\footnotetext{
${ }^{7}$ See Adler-Nissen (2014) on stigma management.

${ }^{8}$ See Paul, Larson, and Wohlforth (2014) on status in IR.

${ }^{9}$ See Neumann (2014) for the need of both material and moral status standards.

${ }^{10}$ Larson, Paul, and Wohlforth (2014:17) argue that high-status states confer status to lesser powers (in addition to other status sources).
} 
International status is about the international role of states and how they are perceived by peers, but the audiences to be impressed include domestic publics, other states, states members of a particular club (e.g. the EU or just fellow participants in negotiations), or foreign publics. NGOs pressure and cajole states to adopt certain positions both domestically and internationally. The two levels are tightly intertwined. Hence, it is better to look at how domestic and international processes of preference change interact rather than treat them as autonomous alternative explanations. This article focuses more on the international level, but what a state does there is clearly linked to NGOs' domestic influence. Still, the strategic organization of international negotiations constrains a state's freedom of action. Its leadership ambitions can be stoked domestically, but they are oriented toward projecting an image internationally.

\section{Cooperative Compromising}

Finally, whether rhetorical coercion works may depend on how far actors push it, especially when they face strong countervailing interests. Thus, after rhetorical entrapment has moved resistant actors closer to the position of norm advocates, space can open up for cooperative interaction that accords equal status to participants who seek a common solution, even if it doesn't result from persuasion. ${ }^{11}$ Cooperative compromising and reciprocal concessions contribute to a sense of ownership of the negotiated outcome. Coupled with positive altercasting, this spurs states to become norm promoters and reap reputation dividends as a result.

\footnotetext{
${ }^{11}$ Müller (2004) argues that when a dead-end is reached by strategic action, actors can switch to communicative action.
} 
According to Schimmelfennig (2003:197) and Krebs and Jackson (2007:36) norm internalization does not follow from rhetorical entrapment and compromise. In contrast, I argue that cooperative compromising and positive altercasting could speed up norm internalization compared to the kind of long norm institutionalization process often posited by constructivists (Risse and Sikkink 1999). Cognitively, cooperative compromising and positive altercasting help participants in negotiations focus not on what they had to sacrifice, but on what they achieved. Norm championship is an advantageous course of action for actors who otherwise might be portrayed as losers in the negotiations. Positive altercasting seeks to solidify actor identification with the role of a norm champion and could thus contribute to norm internalization. This is true especially for those officials closely involved in the negotiation and decision-making processes. However, norm internalization is rarely a straightforward process. As governments and personnel change, their sense of ownership of the norm may weaken. Clashes with countervailing material or ideational pressures can also undermine norm commitments. Still, early positive altercasting and leadership claims open states to scrutiny and rhetorical entrapment at later stages. Thus they are important factors in norm compliance and eventual internalization.

Figure 1 shows a summary of my argument.

Figure 1 


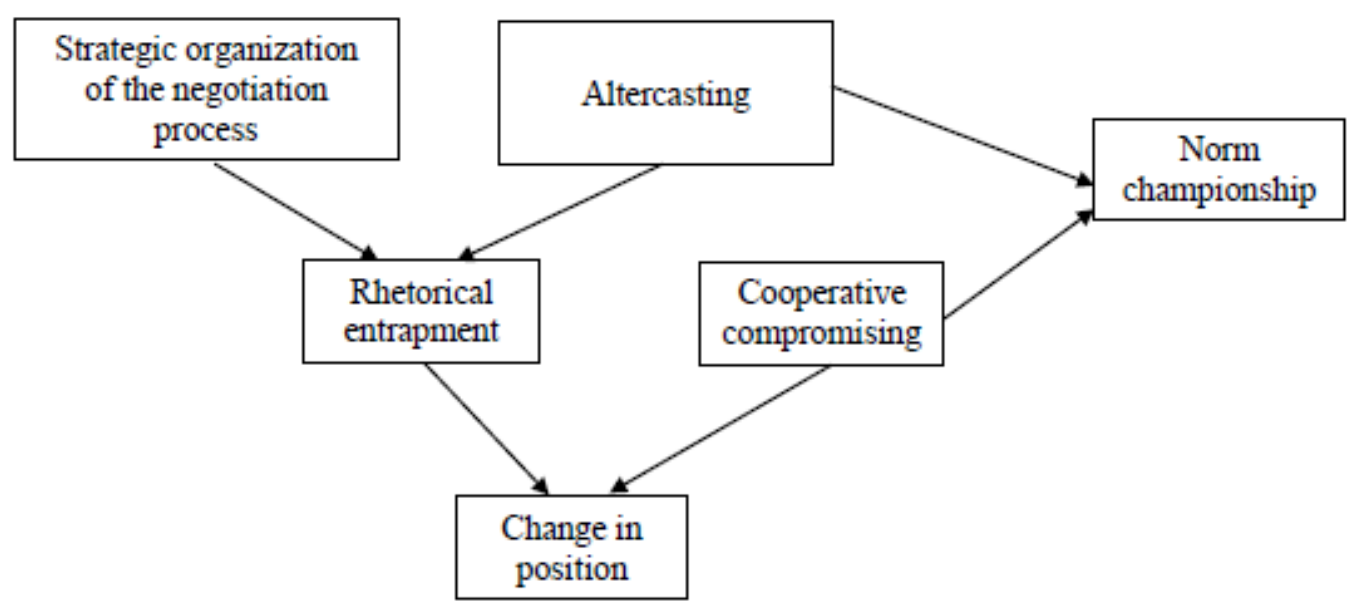

I focus on the UK because it presents a hard case for both genuine persuasion and “rhetorical entrapment," but should have been an easy case for realist approaches based on material power. As a military power that had used cluster munitions, it stood to lose most from a prohibition compared to other negotiation participants. Its delegation was highly knowledgeable about the issues and did not enter the process as a "novice" that could easily change its position (Checkel 2001:563) or fall into an argumentative "trap." Indeed, given that the UK was one of only very few military powers in the negotiations, its support arguably added credibility to the process. This should have provided it with extra leverage over the course of negotiations. Hence, explaining preference change in this doubly "hard" case can help draw conclusions about the general dynamics of international negotiations initiated by weak actors. To do so, I rely on process tracing, twenty-two interviews with government and NGO representatives, examination of the diplomatic record, parliamentary debates, and media coverage, and non-participant observation in 
four negotiation or regional conferences (in Oslo, Brussels, Vienna, and Dublin) that I attended as part of the NGO group or as an individual researcher.

\title{
The Oslo Process to Ban Cluster Munitions
}

\author{
The Cluster Munition Problem
}

Cluster munition is a ground-launched or airdropped rocket/dispenser that "scatter[s] widely smaller submunitions, which usually number in the dozens or hundreds” (Goose 2004:247). ${ }^{12}$ The first problem is that cluster munitions pose immediate dangers to civilians during attacks due to their inaccuracy, large numbers, and wide dispersal. Second, a significant percentage of submunitions fails to detonate upon impact leaving numerous duds, which function as de facto landmines long after use.

Despite these problems, government officials, weapon experts, and even NGOs have argued that cluster munitions have significant military utility. Launching numerous submunitions in one strike is cost-efficient while their area coverage makes them effective against moving targets (United Kingdom 2005; King 2000:37; Pax Christi Netherlands 2005:22, 25). Cluster munitions also represent a large part of some armies' artillery munitions (88 percent in the US; Human Rights Watch 2009:258). Hence, early on government and NGO officials saw the military utility of cluster munitions as an obstacle to their prohibition (personal interviews-20060330-GOV; 20031210-NGO). Nevertheless, their use in several conflicts-Kosovo, Afghanistan, Iraq, and Lebanon- revealed the

\footnotetext{
12 The treaty definition is more technical.
} 
humanitarian problems of cluster munitions and mobilized the movement to banish them from military arsenals and the lives of innocent civilians.

NGOs (including Human Rights Watch, Landmine Action, and Handicap International) and the International Committee of the Red Cross (ICRC) initially strove to include the problem on the agenda of the Convention on Conventional Weapons (CCW). As a result, CCW talks on explosive remnants of war, a category including unexploded submunitions, started in 2001. However, due to consensus-based decision-making and opposition of major military powers, the CCW failed to provide prompt solutions. In 2003, the talks resulted in a Protocol that addressed the post-conflict problems of unexploded ordnance, but didn't cover use of cluster munitions - one of its main causes. According to some diplomats, the Protocol's weakness necessitated action out of CCW (personal interview-20090427.2-GOV). This also prompted the establishment of the Cluster Munition Coalition (CMC) in November 2003 by NGOs willing to work for further regulations. Thereafter, the CCW dragged on discussing the compliance of cluster munition use with international humanitarian law. Even after the 2006 Lebanon War, when Israel's use of cluster munitions elevated the urgency of the problem, states could not agree on starting negotiations. This failure to tackle the humanitarian issue opened the way to a Norwegian initiative for fast-track negotiations out of the CCW, the so-called Oslo Process.

Norway's idea was to set in motion a negotiation only for those countries that had shown interest in banning cluster munitions - a model previously used to ban antipersonnel landmines in the 1990s. The organizers targeted their invitation to countries that were "ready to explore ways to address this pressing humanitarian issue in a 
determined and an effective manner” (Norwegian Ministry of Foreign Affairs 2006) and left it to states to decide whether they wanted to belong to this vanguard group.

\section{Early Altercasting - Igniting Leadership Ambitions}

The initial reaction of UK diplomats was to distance themselves from the Norwegian initiative calling it "foolhardy" (CMC 2006). However, British NGOs and their parliamentarian allies prodded the UK to participate by using positive altercasting. In parliamentary debates, the government was called upon to take "a moral lead" and "set an example by removing...[cluster munitions] from our inventory, just as we have done for landmines” (UK House of Lords 2006; also, UK House of Commons 2006a, 2006b). The projection of the positive image of UK's lead on landmines was key in ban-proponents' efforts to entice the government to measure up current policies to its previous humanitarian achievements.

The government was susceptible to altercasting in the wake of its status loss following the Iraq war debacle. As one parliamentarian argued, it “desperately need[ed] to re-establish its credentials internationally by rebalancing its foreign policy...repositioning...[itself] in the mainstream of Europe and the international multilateral system underpinned by international law” (UK House of Commons 2006a).

The tactic paid off and tied one rhetorical loop around the government - it claimed a leadership role, but tried to evade the altercasters' script for it. The government insisted that "actually" they had "taken the lead in getting the issue discussed among producers and users of cluster weapons [in CCW], because we think that that is the most important” (Foreign Minister Becket in UK House of Commons 2006a) and “took the lead 
in the international community to find a solution"(Minister of State for the Armed Forces Ingram in UK House of Commons 2006b). However, what the government had done was cobble support for a weak CCW mandate to simply discuss cluster munitions - a far cry from what NGOs and likeminded parliamentarians considered leadership - supporting a global, comprehensive ban. The strong pressure exerted by NGOs in the media and parliament reshaped the government's policies (personal interview-20071206-GOV). Eventually, it decided to take part in the Oslo Process for strategic reasons - to claim some leadership credentials, deflect criticisms, and keep action on the issue within bounds.

\section{Setting the "Rhetorical Trap": the Oslo Declaration and Humanitarian Commitment}

The Oslo Process started in February 2007 premised upon agreement that its objective was humanitarian and a prohibition was a means to that end. In their early work, NGOs had demonstrated the severe civilian impact of cluster munitions and thus helped define the humanitarian imperative of negotiations. NGOs drew the analogy between unexploded submunitions and the already banned landmines, thus increasing the resonance of the advocated prohibition by "grafting" it on the prior landmine stigmatization. ${ }^{13}$ The humanitarian imperative became the avowed motivation for participation in the negotiations. Importantly, it also established the common normative framework and the range of arguments regarded legitimate in the negotiations.

Three months earlier, the UK Minister of Armed Forces argued that cluster munitions "are legal weapons, that international humanitarian law is adequate to govern

\footnotetext{
${ }^{13}$ Price (1998:617) on "norm grafting”; on norm and frame resonance, Finnemore and Sikkink (1998), Payne (2001).
} 
their use” (UK House of Commons 2006b). Although ministers acknowledged the humanitarian problems of UK's old submunitions, they only envisioned phasing them out by 2015 when replacement systems were to become available; to do otherwise would "risk leaving... [their] armed forces with a capability gap” (UK House of Commons 2006b). Nevertheless, the UK decided to join the Oslo Process "with the intent to influence it” and make sure "the outcome would have a real relevance in the world" - that it would be acceptable for cluster munition users and producers (personal interviews-20090525.2GOV; 20090526.2-GOV). Hence, the UK joined the process for instrumental reasons - to control it rather than full-heartedly work for the best humanitarian outcome, clearly engaging in strategic action. ${ }^{14}$

However, those who wanted to continue participating in the process, at the end of the conference had to sign the Oslo Declaration. It committed them to a roadmap to conclude by 2008 an international treaty prohibiting "the use, production, transfer and stockpiling of cluster munitions that cause unacceptable harm to civilians”. This wording was a compromise between states, such as the UK, that insisted that only those cluster munitions that cause unacceptable humanitarian harm should be banned and others, such as Mexico, that wanted to prohibit cluster munitions "because they cause unacceptable harm to civilians” (Harrison 2007a, emphasis in original). The phrasing became a "bait” and a “trap” for those that didn’t fully share the organizers' ambitions. The declaration allowed NGOs to argue that no cluster munitions existed that didn’t cause "unacceptable harm,” whereas the UK maintained that only certain (e.g. dumb) munitions should be banned (Human Rights Watch 2009:175). The vagueness became a part of the strategy

\footnotetext{
${ }^{14}$ A WikiLeaks cable corroborates this. According to it, "the UK was participating in both the CCW and the Oslo Process as a 'tactical maneuver' designed to keep activity within the bounds of their 'redlines’” (US Embassy Cables 2010).
} 
behind the process to keep on-board as many states as possible. The main goal was beyond doubt, however - to "effectively address the humanitarian problems caused by cluster munitions” (Oslo Declaration 2007).

By publicly endorsing the humanitarian goal of negotiations, in practice states agreed that self-interested arguments were incompatible with it, and hence, to be accorded little attention. The broadness of the humanitarian goals and the leeway in interpreting them set the conditions for "rhetorically entrapping" the UK that believed it would be able to veer its way into the negotiations and protect its military interests.

In the ensuing discussions the scope for wielding material power was circumscribed, while opportunities to exert moral power were open. Although everyone argued their points in the negotiations, from the beginning it was clear that some states would be the target of pressure and persuasion by leading core states ${ }^{15}$ and NGOs and little space would be left for the opposite.

The UK and "likeminded" countries ${ }^{16}$ favoring a weaker prohibition felt the marginalization of their opinions at the second conference in Lima, where they argued for taking into consideration their military interests (Harrison 2007b). Hence, at the third conference in Vienna in December 2007, they started referring to the terms of the Oslo Declaration, emphasizing that it didn’t envision banning all cluster munitions. Emulating an ICRC wording, they tried to define cluster munitions causing "unacceptable harm" as "inaccurate and unreliable". Thus they sought to exempt from prohibition cluster munitions with a limited number of submunitions, meeting reliability benchmarks, or including self-destruct features. This was a paramount example of a rhetorical move aimed

${ }^{15}$ Austria, Ireland, Mexico, New Zealand, Norway.

${ }^{16}$ This was not a cohesive group and on various issues included Australia, Canada, Denmark, Finland, France, Germany, Italy, Japan, the Netherlands, Slovakia, Spain, Sweden, Switzerland,, , . 
at defending self-interest through normative discourse. However, it was countered by the ICRC explaining that it referred to the characteristics of weapons causing civilian harm and deemed all cluster munitions used to date "inaccurate and unreliable" and to be banned. ${ }^{17}$

A report that documented the situation in Lebanon following the 2006 war also parried the "likeminded" rhetorical move. It found that about 10\% of the M85 submunitions used there failed despite their proclaimed 1-2\% failure rate. It thus showed that civilians could not be protected by simply incorporating self-destruct mechanisms in submunitions (King, Dullum, and Østern 2007). The report became a turning point in the negotiations when many states updated their positions persuaded by the new information.

Still, British delegates remained unconvinced of the statistical representativeness of the report (personal interview-20071206-GOV). But in light of the presented evidence, most states saw the M85 as "unacceptable" and those insisting on balancing humanitarian and military interests found it difficult to justify the permissibility of weapons based on self-destruction alone (personal interviews-20080731-GOV; 20090527.3-GOV; Borrie 2009:188-9). Indeed, around the same time, the UK government decided to accept the prohibition of self-destructing submunitions (personal interviews-20071206-GOV; 20090525.2-GOV; 20090526.2-GOV), a decision reached thanks to the influence of some of the Prime Minister's special advisers closely linked to the NGO community (personal interviews-20090526.2-GOV; 20090525.1-NGO). It also appears that ministers were persuaded by humanitarian arguments and willing to make their decision public. The head of the UK negotiating team, however, acted in a strategic mode. He convinced ministers

\footnotetext{
${ }^{17}$ Author notes, Vienna Conference on Cluster Munitions, 6 December 2007.
} 
not to reveal the decision in order to use it later as a bargaining chip in the negotiations (personal interviews-20090525.2-GOV; 20090525.3-NGO).

With this decision, the UK gave up a new type of submunitions that its military had acquired recently in 2003-04 and wanted to keep in its arsenal. Thus it removed a major obstacle to UK's support for a comprehensive ban on cluster munitions. The timing of the decision challenges an alternative explanation of the UK's change of mind at the final negotiations in May 2008 - that it was due to domestic politics. Namely, Gordon Brown's weak position following a Labour loss in the May 2008 by-elections in a previously Labor-held constituency required showing leadership on an issue that could earn him dividends (Borrie 2009:264). As shown, however, the December 2007 decision predated by several months the domestic political setback. Thus, the latter could have had only a marginal influence on UK's negotiation position, if any.

The other "redline" the UK drew in the final negotiations in Dublin was excluding from prohibition its helicopter-delivered M73 submunitions (personal interview20090525.2-GOV). The UK military was so keen on retaining those submunitions that previously it had renamed them to shield them against a ban. In the final negotiation, the UK made a concerted effort to keep those submunitions, yet, diplomats acknowledged that their "arguments soon became untenable" (personal interview-20090526.2-GOV). They could not convince other states that simply because a munition had a limited number of submunitions or was "direct-fire," it did not produce humanitarian effects. The UK became entangled in a spiral of argumentative exchanges that gradually expanded the scope of the prohibition. In the words of a UK delegate, despite joining the negotiations with the intent of influencing them, “the process didn’t allow it” (personal interview20090526.2-GOV). 
This rules out another alternative explanation of the British change in preferences focused on learning processes - that the UK accepted the treaty because along the way it realized that a prohibition would be less costly in military or economic terms than initially thought. As shown, the UK maintained it had military needs for M85 well into 2007 and for the M73 submunitions till the very end of negotiations. Moreover, without the impact of negotiations, a rapid change in assessments of military requirements cannot be explained. One could also argue that the military and British arms producers were to benefit from replacing banned cluster munitions with advanced sensor-fuzed weapons. However, Britain was not producing such weapons. All British cluster munitions were banned (including recently acquired ones) and their destruction carried a significant cost. Britain did not join the treaty because it entailed a cheap commitment. Rather, it had to switch its negotiation position in order to keep up its proclaimed humanitarian commitment.

\section{Shifting the Mean Preference and Numerical Balance of Power}

The Oslo Process comprised five negotiation conferences focused on the treaty text and seven regional meetings to attract new states. To increase participation, the leading states financed a sponsorship program through the UN Development Program that covered the expenses of delegates from developing countries and aimed at leveling the playing field. At the same time, the strategic thinking was that this would result in bigger numbers of staunch supporters and limit the leverage of states that didn't favor a comprehensive prohibition. 
The regional meetings, devised to explain the stakes in negotiations and consolidate regional positions, were key in the process. The African conference was a case in point, since the majority of African countries had not participated in the prior CCW talks and lacked detailed knowledge of the problem. In the words of an NGO member, the conference goal was to "educate" government officials of the issues and "empower them to play a more active role” (personal interview-20080517-NGO). However, the leading countries and NGOs didn't proceed from an entirely disinterested position. According to a CMC representative, the goal was to "provide information and whip up support" and "give [countries] the arguments they could argue for us" (personal interview-20090527.4NGO). A core-group diplomat similarly stated that regional meetings were "strategically" organized to attract radical supporters to the process and encourage countries that "had the right to speak up loudly as affected countries” (personal interview-20090427.1-GOV). This was a strategically-orchestrated process to help African policymakers formulate their positions, including by altercasting them as leaders whose "voice will speak volumes and win the day" (CMC 2008).

The African countries came up with a strong stance aligned with NGO recommendations. They favored a prohibition of "all cluster munitions that cause unacceptable harm" that "should be total and immediate” (Nash 2008) - a position that surpassed what Norway, the leader of the process, was advocating. However, it also enabled Norway to position itself "in the golden mean and play the mediator role” between radical ban supporters and opponents (personal interview-20090427.2-GOV).

And the strategy seemed to work - already at the Vienna conference in December 2007, cluster munition users and producers chafed at the increasing numbers of developing countries advocating a total ban. According to British delegates, since such countries had 
limited understanding of the issues, did not possess cluster munitions, for the most part had no contamination problems, and were not involved in military action, they had no "equity" in influencing the negotiations (personal interviews-20071206-GOV; 20090525.2-GOV). This attitude underscores the lack of equal respect among participants required for communicative action, but also that the process depended more on strategic than communicative action.

The strategy also worked together with rhetorical entrapment in the final negotiations in May 2008, when the UK and "likeminded" states tried to include in the treaty a provision allowing for transition periods for prohibited munitions. In regional conferences in Africa and Latin America, NGOs had been highlighting the moral inconsistency of banning weapons because of their unacceptable humanitarian harm and preserving the right to use them for a period because of military considerations. When the issue came up for discussion at the final negotiation, one developing country after another rose up to speak against it, effectively burying it down. ${ }^{18}$

\section{Agenda Control and "Moral Blackmailing” - Tightening the Loop of Rhetorical Entrapment}

State positions changed at the penultimate conference in Wellington in February 2008. Instead of defending as before broad exclusions based on a single criterion, such as selfdestruction, most states suggested that a combination of criteria would prevent unacceptable civilian harm. Importantly, states referred consistently to the goals of the Oslo Declaration and their own humanitarian credentials. The UK emphasized its staunch

\footnotetext{
${ }^{18}$ Author notes, Dublin Diplomatic Conference on Cluster Munitions, 23 May 2008.
} 
support for the Oslo Process and humanitarian assistance in clearing cluster munitions in Lebanon (United Kingdom 2008). As earlier arguments about military interests had not carried the day, now negotiators saw the need to play up UK's humanitarian commitments.

At Wellington, the strategic approach behind negotiations reached its apogee. Until then organizers fully controlled the agenda of the process. In previous meetings, states such as the UK, France, and Germany were tabling proposals to narrow the scope of the prohibition, but they were not reflected in the drafts the leading states prepared for each consecutive conference. Instead, the core group kept strengthening the draft until Wellington where it had to be finalized and sent to the last conference as the basis for negotiation of the future convention text.

From the beginning, the UK and "likeminded" states criticized the process's lack of transparency (personal interviews-20071030-GOV; 20071207-GOV). As much as they were engaging in discussions, their views were left unheeded. Simultaneously, national and international NGOs exerted heavy pressure and questioned those states' "authenticity" as sincere participants in the talks or accused them of catering to the interests of the US, itself absent from the negotiations. ${ }^{19}$ A host of African and Latin American countries also became more vocal in advocating a total ban. This led to a critical moment when the "likeminded" pushed back and the UK threatened to leave the process if its proposals were not included in the draft (personal interviews-20080731; 20090525.2GOV). British and "likeminded" delegates portrayed the process as "very confrontational," "a bitter process of negotiation", "moral blackmailing and moral bullying", the core group as "immune to persuasion" and "not trying to persuade"

\footnotetext{
${ }^{19}$ Domestic pressure was strongly felt in Britain, France, and Canada (personal interviews 20071206GOV; 20090525.2-GOV; 20090526.2-GOV; 20090527.3-GOV; 20090526.3-NGO).
} 
(personal interview-20090525.2-GOV) and the needs of countries for ban exemptions "totally ignored" (personal interview-20090526.2-GOV). Others asked "what kind of negotiation is that if only one side is listened to?” (personal interview-20090527.3-GOV).

As a result, the proposals of the "likeminded" were included in a draft compendium. This concession was enough to keep them onboard and they signed the Wellington Declaration committing themselves to negotiate the final treaty based on the text agreed in Wellington. The core countries used the declaration as an "admission ticket" for participants in the concluding negotiations - once again before the endgame states had to publicly commit to the humanitarian goal of the process.

Thus, the leading states and their NGO partners kept momentum behind the process. But the way in which they achieved this did not epitomize open communicative action. The portrayal of parts of the negotiations as "moral blackmailing" had some truth to it and core state representatives described the Wellington confrontation between "likeminded” and total ban proponents as "staged” (personal interview-20121115-GOV). However, the negotiations were premised on agreement that most cluster munitions posed unacceptable humanitarian harm that had to end. Proposals motivated by military and economic considerations went against this humanitarian approach. Hence, they were not perceived as legitimate and were excluded from the evolving draft text - a conscious decision by the organizers who wanted to avoid discussions that threatened to "grind the process down” (personal interview-20071205-GOV). In the meantime, despite its dissatisfaction with the process, the UK kept "sinking" its political capital in it.

Cooperative Compromising - a Step to Norm Acceptance 
At the final negotiations in Dublin in May 2008, the core states stepped back from "shepherding" the process (Borrie 2009:285). According to delegates both from the "likeminded", defending exclusions from the future prohibition and concerned about interoperability in joint operations with non-states parties, and developing states supporting a total ban, the president of the conference, Ambassador O'Ceallaigh, was key in reconciling differences and enabling dialogue (personal interviews-20090525.2-GOV; 20090526.2-GOV; 20090527.1-GOV). Prior to Dublin, he talked at length to state representatives and assured them their concerns would be taken into account. And he became convinced that the "likeminded" were committed to the process and "wanted to conclude a good convention” (personal interview-O’Ceallaigh). Arguably, this approach marked a shift from strategic action and toned down its polarizing effects. NGOs also placed emphasis on less confrontation and more "positive messages" (personal interview20090527.2-NGO). Bargaining still permeated the final negotiations, but interlocutors participated on equal footing without openly questioning each other's "authenticity.” They tried to reach a common position in a process approximating "cooperative" or “integrative” bargaining” (Thomas 2009; Reh 2011).

At the start of the conference, the UK and most "likeminded" states insisted that a combination of technical features would prevent the humanitarian effects of cluster munitions. This "cumulative" approach clashed with the position of African and Latin American states for a total prohibition, with some core states such as Norway in the middle supporting a prohibition of most munitions except advanced sensor-fuzed weapons.

As already shown, the UK's efforts to exclude from prohibition its M73 submunitions did not succeed, because they contradicted the humanitarian imperative established at the outset of negotiations. The UK faced a choice to walk out of the 
negotiations and pay the political price, or change its position and reap political benefits from championing the humanitarian cause. In light of domestic NGO pressure and prior claims to leadership of the ban process, the government was unwilling to do the former and in a bold change of course, the Prime Minister threw British support behind the process.

In the end, the treaty resulted from compromise and linkages between the definition and other provisions, especially those on interoperability (personal interviews-20090525.2; 20090526.1-GOV). ${ }^{20}$ Its overall scope, however, had already come as close as possible to the humanitarian objective charted at the beginning. While the most advanced cluster systems were not banned, they were portrayed as not having the same kind of humanitarian effects as cluster munitions, posing a lower threat to civilians than unitary munitions (personal interview-20080702-GOV). In a world of "moral limit and possibility" (Price 2008) this was a choice between a total prohibition that yields a marginal amelioration of the humanitarian situation, but alienates a group of important states, and a compromise that receives the support of those states without jeopardizing the treaty's humanitarian goal.

The conference president presented a package that nobody challenged because they considered it a "balanced" deal that would unravel if countries sought to pursue further their preferred solutions. ${ }^{21}$ It was a compromise that did not necessarily persuade but was acceptable to everyone - everyone agreed the treaty text was balanced. In the

\footnotetext{
${ }^{20}$ On the insistence of the UK and other "likeminded" states (especially Canada and Australia), an interoperability article was added aimed at ensuring that states-parties could legally engage in joint operations with non-states parties, despite Article 1's prohibition to "assist, encourage or induce anyone to engage in any activity prohibited”, i.e. using, developing, producing, acquiring, stockpiling, retaining or transferring cluster munitions.

${ }^{21}$ Summary Record of $16^{\text {th }}$ Session of the Committee of the Whole, Dublin Conference, 28 May 2008.
} 
words of a Dutch delegate, they were not happy with the text, but "unhappiness [wa]s evenly distributed among states." ${ }^{22}$ Negotiators from leading states claimed it was "the best possible text" and "the best convention we could have had" (personal interviews20090526.1; 20090427.2-GOV). NGOs proclaimed it "exceed[ed] the expectations of nearly everyone” (Human Rights Watch 2008). Even the British, who warned in the wake of the process that it was a "dangerous" undertaking that should not serve as a model, admitted it had produced a "win-win treaty" (personal interview-20090525.2GOV), "the best possible consensus" resulting from "balancing humanitarian and security concerns." ${ }^{23}$

Still, could it alternatively be argued that the compromise reflected UK interests and was due to its hard bargaining? Although UK's participation was valued, especially by the Irish (personal interview-20090526.1-GOV), the only point on which the UK secured its preferences was interoperability, a provision with questionable practical relevance (personal interview-20090427.2-GOV). ${ }^{24}$ If its bargaining power mattered, the UK should have been able to secure treaty provisions more closely aligned with its "redlines." Instead, the final treaty prohibition was much broader than its preferences. Indeed, while arguing that the treaty was a "win-win" outcome, a UK official recalled to have said to NGO members at the negotiations' end, "shut up, you've won!” (personal interview-20090525.2-GOV).

${ }^{22}$ Author notes, Dublin Conference, 28 May 2008. In their concluding statements, 38 states (or NGOs) referred to the text as "the best possible compromise", a "balanced text," or mentioned the concessions everyone had to make. 17 statements referred to it as an advancement of international humanitarian law, mentioned its humanitarian character, or characterized it as "excellent" (Summary Record, Committee of the Whole, Dublin Conference, 28 May 2008).

${ }^{23}$ Dublin Conference, Committee of the Whole, 28 May 2008.

${ }^{24}$ Since treaty adoption, the US has not used cluster munitions in joint operations with signatories. 
The negotiation outcome was a compromise that took into account different interests, but was not the lowest common denominator as it pulled reluctant states, such as the UK, as close as possible to a comprehensive ban of all cluster munitions shown to cause humanitarian harm. In the end, all participants engaged in the process of making the treaty and their most important interests were taken into account. Eventually, this created a feeling of common entrepreneurship that paved the way to norm championship.

\section{Altercasting and Norm Championship}

As the immediate negotiation experience wore off, the sense of pride and ownership by those who contributed to the Convention grew and attached them closer to the humanitarian role they had played and would be expected to play in the future.

Already at the closing plenary in Dublin, compared to two days before (footnote 22), the number of states framing the outcome as humanitarian achievement vs. a compromise had reversed - of 47 states making a statement, 24 characterized the treaty as a "milestone" of international humanitarian law or mentioned its humanitarian character, while 12 portrayed it as a compromise balancing different interests. By the time of the signing ceremony in December 2008, states became entirely focused on the humanitarian achievement and their pride to be part of it. Upon "proudly" signing, the British Foreign Secretary extolled the Convention as "the most significant disarmament treaty of recent years" and pledged UK's commitment "to secure the widest possible adherence to our new Convention” (Miliband 2008). Next, the UK started destroying its weapon stocks and the government stated that "in keeping with ... [the convention] spirit, the UK would seek the removal of all foreign stockpiles of cluster munitions from 
UK territory” (Human Rights Watch 2009:178). Upon the introduction of the cluster munitions bill in parliament, the head of the UK negotiation team, Ambassador John Duncan, who had previously questioned the humanitarian credentials of NGOs working on issue (Duncan 2006), extolled the Convention "as a testament to what can be achieved when Government, civil society and parliamentarians work together” and reasserted that “UK leadership helped secure this significant step” (Duncan 2009). In March 2010, the UK adopted its national legislation and ratified the Convention in May. Upon the law passage, the Prime Minister expressed his "huge pride" that "Britain is leading the world in banning the use of these munitions" and pledged to work for a global ban (UK Foreign and Commonwealth Office 2010). Looking back at the Oslo Process, Ambassador Duncan asserted the sincere British commitment in the negotiations, commended the important role of survivors in it, and argued that "the world is a better place for the existence of the Oslo Treaty” (Duncan 2010).

As shown, from the beginning British NGOs and their parliamentarian allies have urged the UK government to play a leading role in banning cluster munitions the way it had on landmines. Initially, the government only claimed to be a leader without living up to the demands of leadership posed by NGOs. But eventually, it moved along the way charted by the NGOs that monitored, chastised, or praised it upon each step. When the UK joined the process and signed the Oslo Declaration, NGOs commended its "real leadership" that "would create an unstoppable impetus towards a treaty" and urged it further to "dispose of their stockpile of 'dumb cluster munitions”" (Penketh 2007; Landmine Action 2007a). A month later, the Ministry of Defense indeed announced it was banning its "dumb” submunitions, boasting "the UK was the first world power to abandon the munitions" and others would hopefully "follow suit" 
(Britain Becomes First World Power 2007). NGOs acknowledged that was "highly significant," but insisted that self-destruct submunitions remaining in the British arsenal should also be banned (Landmine Action 2007b). The military dragged its feet and even tried to protect its M73 submunitions by changing their categorization. NGOs accused it of "hypocrisy" and "spinning a cluster bomb con" instead of championing a ban treaty the way it had done on mines (Norton-Taylor 2007). As the government was trying to claim a leading role, the bar for that was being raised and NGOs continuously questioned UK's commitment to protecting civilians when its actions fell short of supporting an unequivocal ban (Landmine Action 2007c). They were enticing and pressuring the UK into assuming leadership, while the government was playing catch-up. Just before UK's change in policy in Dublin, NGOs admonished again that "[i]f Britain wishes to continue to paint itself as a leader in the cluster ban movement," it should support a total ban (Williams 2008). To do less would have unleashed a wave of criticism and shown the government's earlier assertions hollow.

The government finally lived up to its leadership aspirations following Gordon Brown's policy U-turn in May 2008. It called for banning all British cluster munitions and was portrayed as a turning point in the Dublin negotiations (Brown 2008). British NGOs offered positive reinforcement by praising the government and certifying its humanitarian credentials - "The UK is now showing strong humanitarian leadership,” and urged recalcitrant states "to follow the UK's lead and show equal humanitarian commitment” (Oxfam and Landmine Action 2008; also Landmine Action and Oxfam 2008a,b; Landmine Action, Oxfam, DPWMF 2008). At long last, the government fell in line with the role NGOs have all along been projecting for it through negative and positive altercasting. 
Casting of the UK as a leader in banning cluster munitions became again prominent in the media in November 2011 in the context of urging it to withstand US pressure for adopting a weaker treaty within the CCW that would have allowed the use of cluster munitions already prohibited by the Convention. ${ }^{25}$ Parliamentary debates on this issue prompted reaffirmations of British commitment to the treaty from the new Conservative government (House of Commons 2011; House of Lords 2011). This fed into the construction of a UK leading international role on disarmament and humanitarian issues that the previous government had charted arguing that the Convention adoption "builds on the UK's leadership on arms control... [and would] bolster our reputation as a champion for change” (UK Foreign and Commonwealth Office 2009). ${ }^{26}$

Consistency between UK policy and treaty obligations would indicate that a transition from rhetorical entrapment and rhetorical norm championship to norm internalization may be underway. A mere tactical concession at the negotiations could result in ratification delays, narrow interpretation of treaty provisions, or attempts to exploit loopholes. ${ }^{27}$ So far, the UK has been a champion of the treaty and promoted its

\footnotetext{
${ }^{25}$ E.g., "the UK has played a leading role in trying to rid the world of cluster bombs;" "UK's role in securing an international ban on cluster bombs in 2008 showed the best of what Britain can do in the world" (quoted in Taylor 2011); "The UK has quite rightly championed the total ban on cluster munitions" (Norton-Taylor 2011).

${ }^{26}$ Upon signing the Convention on Cluster Munitions, Foreign Secretary Miliband argued about Britain "taking a strong lead in disarmament" (Miliband and Steinmeier 2008). Upon ratification, the UK Foreign and Commonwealth Office (2010) claimed it showed "UK's continued leadership on arms control, from landmines to the Arms Trade Treaty.” The new foreign secretary acknowledged the Convention as an important achievement that the new government would consolidate (Hague 2010). See also, Cluster Munition Monitor (2010: 108) about the new government's commitment to the treaty.

${ }^{27}$ A WikiLeaks cable released on 1 December 2010 seemed to show the government wanted to mislead parliament about an agreement with the US to permit transit of cluster munitions over UK
} 
universalization. It was also one of the first states to destroy its cluster munitions five years before the mandated deadline despite holding the largest stockpile among all signatory states (Cluster Munition Monitor 2010: 108-109, 2013; CMC 2013). Yet, while reaffirming its "full and continuing support" for the cluster munition ban and its universalization (UK 2015), the UK has recently refrained from condemning all use of cluster munitions, and in particular, the use by an ally, Saudi Arabia. NGOs strongly criticized its stance and highlighted the discrepancy between British leadership claims and refusal to condemn all cluster munition use (Article 36 2015). Once again, the UK was doubly entrapped by its prior commitment to the treaty and its claims to be a norm leader. Although the UK's road to norm acceptance has been riddled with obstacles and countervailing interests, as its NGO critics argue, "the humanitarian imperative toward civilian protection has still dictated the central elements of UK policy at critical moments" (Article 36 2015: 2). As this article showed, the ability of norm entrepreneurs to rhetorically entrap the UK through negative and positive altercasting was key in influencing its course of action.

\section{Conclusion}

The article shows that rhetorical entrapment can work not only in the domestic or regional domain where norms are dense, but also at the international level where common values

territory by "temporary exception." However, in parliamentary debates in March 2010 (before the WikiLeaks release), the government stated that the Secretary of State could grant permission to transit. The only permission given was in the context of removing US cluster munitions from UK territory (Cluster Munition Monitor 2013). 
form a thinner layer. Whereas scholars usually attribute the success of weak actors in international negotiations to the persuasive power of their arguments, this article stresses how strategic action by small states and NGOs proves crucial in engineering the conditions for rhetorical entrapment in the international arena. I link rhetorical entrapment and norm acceptance by showing how two processes shape the latter - an evaluation of the fairness of the decision-making process as attested to by comparable sacrifices on all sides (cooperative compromising) and how NGO participants stoke a state's desire to 'look good' (positive altercasting).

Although there are no general rules determining when altercasting works, I suggest that it can be effective in cases when, first, states seek to enhance their status, and second, when NGOs actively engage in praising and shaming them both internationally and domestically. Future research needs to specify better the conditions under which strategic manipulation is likely to succeed, and especially, how positive and negative altercasting can be combined to that end. So far scholars have paid abundant attention to social pressure in international politics. A focus on social encouragement and approval can reveal important new political dynamics and pathways to norm creation.

\section{References}

Adler-Nissen, Rebecca. (2014) Stigma Management in International Relations:

Transgressive Identities, Norms, and Order in International Society. International Organization 68(1): 143-176.

Article 36. (2015) Refusal to Condemn Cluster Munition Use Undermines UK Claims to Leadership on the Protection of Civilians. Briefing paper, September. 
http://www.article36.org/wp-content/uploads/2015/09/UK-and-cluster-munitions2015.pdf

Bellamy, Richard. (1999) Liberalism and Pluralism: Toward a Politics of Compromise. London and New York: Routledge.

Bially Mattern, Janice (2011) A Practice Theory of Emotions for International Relations. In International Practices, eds. Emanuel Adler and Vincent Pouliot, 6386. Cambridge: Cambridge University Press.

Bjola, Corneliu and Markus Kornprobst, eds. (2011) Arguing Global Governance: Agency, Lifeworld and Shared Reasoning. London and New York: Routledge.

Bleiker, Roland and Emma Hutchison. (2008) Fear No More: Emotions and World Politics. Review of International Studies 34(S1): 115-135.

Bleiker, Roland and Emma Hutchison, eds. (2014) Forum: Emotions and World Politics. International Theory 6(3): 490-594.

Blyth, Mark. (2007) Powering, Puzzling, or Persuading? The Mechanisms of Building Institutional Orders. International Studies Quarterly 51(4): 761-777.

Borrie, John. (2009) Unacceptable Harm: A History of How the Treaty to Ban Cluster Munitions Was Won. New York and Geneva: United Nations Publications.

Britain Becomes First World Power to Ban Use of “Dumb” Cluster Bombs (2007) Independent, March 21, p.18

Brown, Colin. (2008) UK Leads the Way as Summit Agrees Ban on Cluster Bombs. Independent, May 29, p. 6.

Checkel, Jeffrey T. (2001) Why Comply? Social Learning and European Identity Change. International Organization 55(3): 553-588. 
Cluster Munition Monitor. (2010) Report. < http://www.themonitor.org/cmm/2010/pdf/CMM_2010_pdf.pdf> (Accessed 18 August 2014).

Cluster Munition Monitor. (2013) United Kingdom Report. $<$ http://www.themonitor.org/index.php/cp/display/region_profiles/theme/3135> (Last updated 3 September 2013, accessed 12 August 2014).

CMC (Cluster Munition Coalition) (2006) November Bulletin. <http://web.archive.org/web/20070731091039/http://www.stopclustermunitions.org/ news.asp?id=45> (Accessed 23 March 2007).

CMC (Cluster Munition Coalition) (2008) Strong African Voice Needed for Cluster

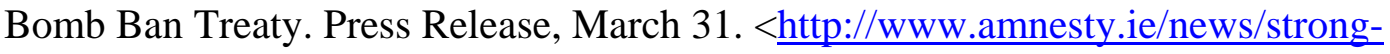
african-voice-needed-cluster-bomb-ban-treaty $>$ (Accessed 25 April 2008).

CMC (Cluster Munition Coalition) (2013) UK Destroys Last Stockpiled Cluster Munition. CMC News, December 19. < http://www.stopclustermunitions.org/engb/media/news/2013/uk-destroys-last-stockpiled-cluster-munition.aspx > (Accessed 12 August 2014).

Coleman, Katharina P. (2013) Locating Norm Diplomacy: Venue Change in International Norm Negotiations. European Journal of International Relations 19(1): 163-186.

Crawford, Neta C. (2000) Passion of World Politics: Propositions on Emotion and Emotional Relationships. International Security 24(4): 116-156.

Crawford, Neta C. (2002) Argument and Change in World Politics: Ethics, Decolonization, and Humanitarian Intervention. Cambridge: Cambridge University Press. 
Crawford, Neta C. (2009) Homo Politicus and Argument (Nearly) All the Way Down: Persuasion in Politics. Perspectives on Politics 7(1): 103-24.

Crawford, Neta C. (2013) Emotions and International Security: Cave! Hic Libido. Critical Studies on Security 1(1): 121-23.

Deitelhoff, Nicole. (2009) The Discursive Process of Legalization: Charting Islands of Persuasion in the ICC Case. International Organization 63(1): 33-65.

Deitelhoff, Nicole and Harald Müller. (2005) Theoretical Paradise-Empirically Lost? Arguing with Habermas. Review of International Studies 31(1): 167-179.

Diez, Thomas and Jill Steans. (2005) A Useful Dialogue? Habermas and International Relations. Review of International Studies 31(1): 127-140.

Duncan, John. (2006) Statement, Final Plenary Meetings, CCW Review Conference, 17 November. http://www.unog.ch/80256EDD006B8954/\%28httpAssets\%29/795C8B9DF05605D BC12572300030F7C1/\$file/1036.MP3.

Duncan, John. (2009) Oslo Treaty to Ban Cluster Munitions. Blog, 20 November. http://web.archive.org/web/20100129123029/http://blogs.fco.gov.uk/roller/duncan/e ntry/oslo_treaty_to_ban_cluster.

Duncan, John. (2010) The Oslo Treaty: Looking back on the Negotiations. Blog, 4 November. http://web.archive.org/web/20120205145729/http://blogs.fco.gov.uk/johnduncan/201 0/11/04/the-oslo-treaty-looking-back-on-the-negotiations/.

Evangelista, Matthew. (2001) Norms, Heresthetics, and the End of the Cold War. Journal of Cold War Studies 3(1): 5-35. 
Fierke, K.M. (2013) Political Self Sacrifice: Agency, Body and Emotion in International Relations. Cambridge: Cambridge University Press.

Finnemore, Martha and Kathryn Sikkink. (1998) International Norm Dynamics and Political Change. International Organization 52(4): 887-917.

Glasius, Marlies. (2008) Does the Involvement of Global Civil Society Make International Decision-Making More Democratic? The Case of the International Criminal Court. Journal of Civil Society 4(1): 43-60.

Goffman, Erving. (1959) The Presentation of Self in Everyday Life. New York: Anchor.

Goose, Steve. (2004) Cluster Munitions: Toward a Global Solution. In HRW World Report, 245-278. January.

Gurowitz, Amy. (2006) The Diffusion of International Norms: Why Identity Matters. International Politics 43(3): 305-341.

Habermas, Jürgen. (1984) The Theory of Communicative Action. Vol. 1. Boston: Beacon Press.

Hague, William. (2010) Britain's Values in a Networked World. Speech, September 15. <https://www.gov.uk/government/speeches/foreign-secretary-britains-values-ina-networked-world> (Accessed 10 January 2011).

Hanrieder, Tine. (2011) The False Promise of the Better Argument. International Theory 3(3): 390-415.

Harnisch, Sebastian, Cornelia Frank, and Hanns W. Maull, eds. (2011) Role Theory in International Relations: Approaches and Analyses. New York: Routledge.

Harrison, Katherine. (2007a) Report from the Oslo Conference on Cluster Munitions, February. <http://www.bandepleteduranium.org/en/report-from-the-oslo-conferenceon-cluster-munitio > (Accessed 15 May 2014). 
Harrison, Katherine. (2007b) Report from the Lima Conference on Cluster Munitions, 25-27 May.

$<$ https://web.archive.org/web/20080523180206/http://www.wilpf.int.ch/disarmament /clustermunitions/LIMA/limareport.html> (Accessed 30 July 2015).

Hubert, Don. 2000. The Landmine Ban: A Case Study in Humanitarian Diplomacy. Occasional Paper 42, Thomas J. Watson Jr. Institute of International Studies. http://www.watsoninstitute.org/pub/op42.pdf (Accessed 15 March 2015).

Human Rights Watch. (2008) Cluster Munition Coalition Statement to the Committee of the Whole on the Agreement to Adopt the Cluster Munitions Convention. Dublin, May 28. < https://www.hrw.org/news/2008/05/28/cluster-munition-coalition-statementcommittee-whole-agreement-adopt-cluster $>$ (Accessed 10 June 2014).

Human Rights Watch. (2009) Banning Cluster Munitions: Government Policy and Practice. Report, May. < http://www.themonitor.org/cm/2009/banning_cluster_munitions_2009.pdf $>$ (Accessed 19 August 2014).

Jeffery, Renée. (2014) Reason and Emotion in International Ethics. Cambridge: Cambridge University Press. Kindle edition.

Johnstone, Ian. (2011) The Power of Deliberation, International Law, Politics and Organizations. Oxford: Oxford University Press.

Keck, Margaret E. and Kathryn Sikkink. (1998) Activists beyond Borders: Advocacy Networks in International Politics. Ithaca, NY: Cornell University Press. King, Colin (2000) Explosive Remnants of War: A Study on Submunitions and Other Unexploded Ordnance. Report distributed by the International Committee of the Red Cross, August. 
King, Colin, Ove Dullum and Grethe Østern. (2007) M85: An Analysis of Reliability. Report, December. $<$ http://www.npaid.org/content/download/1142/10896/file/m85.pdf $>$ (Accessed 15 June 2015).

Kornprobst, Markus. (2007) Argumentation and Compromise: Ireland's Selection of the Territorial Status Quo Norm. International Organization 61(1): 69-98.

Kornprobst, Markus. (2014) From Political Judgements to Public Justifications (and vice versa): How Communities Generate Reasons upon which to Act. European Journal of International Relations 20(1): 192-216.

Krebs, Ronald R. and Patrick Thaddeus Jackson. (2007) Twisting Tongues and Twisting Arms: The Power of Political Rhetoric. European Journal of International Relations 13(1): 35-66.

Landmine Action. (2007a) 46 Nations Commit to Ban Cluster Bombs. Press Release, February 23.

$<$ http://web.archive.org/web/20111103180133/http://www.landmineaction.org/resourc es/resource.asp?resID=1037> (Accessed 14 June 2015).

Landmine Action. (2007b) UK Moves Closer to Cluster Bomb Ban, but Keeps Unacceptable Weapons for Use. Press Release, March 19. $<$ http://web.archive.org/web/20111103181336/http://www.landmineaction.org/resourc es/resource.asp?resID=1042> (Accessed 30 March 2015).

Landmine Action. (2007c) Agencies Accuse UK Government of Reclassifying Cluster Bomb in order to Beat the Weapon's Ban, September 18. <http://web.archive.org/web/20111103102515/http://www.landmineaction.org/resou rces/resource.asp?resID=1082 > (Accessed 16 June 2015). 
Landmine Action and Oxfam. (2008a) Groundbreaking Treaty Banning Cluster Bombs Achieved. Press Release, May 29.

$<$ http://web.archive.org/web/20081007155146/http://www.landmineaction.org/resou rces/resource.asp?resID=1096> (Accessed 16 June 2015).

Landmine Action and Oxfam. (2008b) Cluster Bomb Ban: Common Sense and Common Humanity Prevail Say Campaigners. Press Release, May 30.

<http://web.archive.org/web/20081007161458/http://www.landmineaction.org/resou rces/resource.asp?resID=1097> (Accessed 16 June 2015).

Landmine Action, Oxfam, and DPWMF. (2008) World Leaders Make Major Step Forward on Arms Control. Press Release, December 2. <http://web.archive.org/web/20081220020021/http://www.landmineaction.org/resou rces/resource.asp?resID=1107> (Accessed 21 August 2015).

Larson, Deborah Welch, T.V. Paul, and William C. Wohlforth. (2014) Status and World Order. In Status in World Politics, eds., T.V. Paul, Deborah Welch Larson, and William C. Wohlforth, 3-29. New York: Cambridge University Press. Kindle edition.

Mercer, Jonathan. (2013) Emotion and Strategy in the Korean War. International Organization 67(2): 221-252.

Miliband, David. (2008) Statement on Signing the Convention on Cluster Munitions, Oslo, December 3.

$<$ http://www.osloccm.no/pop.cfm?FuseAction=Doc\&pAction=View\&pDocumentId=1 7963> (Accessed 10 July 2014).

Miliband, David and Frank Walter Steinmeier. (2008) Towards a Safer World: By Signing the Convention on Cluster Munitions, Germany and Britain Are Taking a 
Strong Lead in Disarmament. Guardian, December 2.

$<$ http://www.theguardian.com/commentisfree/2008/dec/02/weaponstechnologyarmstrade> (Accessed 14 May 2014).

Morin, Jean-Frédéric and E. Richard Gold. (2010) Consensus-Seeking, Distrust and Rhetorical Entrapment: The WTO Decision on Access to Medicines. European Journal of International Relations 16(4): 563-587.

Müller, Harald. (2004) Arguing, Bargaining and All That: Communicative Action, Rationalist Theory and the Logic of Appropriateness in International Relations. European Journal of International Relations 10(3): 395-435.

Neumann, Iver B. (2014) Status Is Cultural: Durkheimian Poles and Weberian Russians Seek Great-Power Status. In Status in World Politics, eds., T.V. Paul, Deborah Welch Larson, and William C. Wohlforth, 85-112. New York: Cambridge University Press. Kindle edition.

Norton-Taylor, Richard. (2007) Human Rights Groups Accuse MoD of Hypocrisy over Cluster Bombs. Guardian, September 18.

$<$ http://www.theguardian.com/politics/2007/sep/18/uk.military > (Accessed 22 September 2007).

Norton-Taylor, Richard. (2011) UK Resists US Efforts to Relax Laws Banning Cluster Bombs. Guardian, November 23, p.20.

Oslo Declaration. (2007) Oslo Conference on Cluster Munitions, 22-23 February. Declaration.

http://web.archive.org/web/20150914162140/http://www.clusterconvention.org/files/2 012/11/Oslo-Declaration-final-23-February-2007.pdf 
Oxfam and Landmine Action. (2008) Brown Commits to Banning All Cluster Bombs.

Press Release, May 28. < $\underline{\text { http://www.stopclustermunitions.org/en- }}$

gb/media/news/2008/brown-commits-to-banning-all-cluster-bombs.aspx > (Accessed

19 May 2010).

Nash, Thomas. (2008) Report on the Livingstone Conference on Cluster Munitions, April 3. < http://www.stopclustermunitions.org/en-gb/media/news/2008/cmc-reporton-the-livingstone-conference.aspx> (Accessed 19 May 2010).

Norwegian Ministry of Foreign Affairs. (2006) Invitation Letter to the Oslo Conference by Jonas Gahr Støre. December.

< $\underline{\text { http://www.clusterconvention.org/files/2012/12/CCW-Invitation-letter.pdf }>}$ (Accessed 15 August 2014).

Panke, Diana. (2010) Why Discourse Matters Only Sometimes: Effective Arguing beyond the Nation-State. Review of International Studies 36(1): 145-168.

Paul, T.V., Deborah Welch Larson, and William C. Wohlforth, eds. (2014) Status in World Politics. New York: Cambridge University Press. Kindle edition.

Pax Christi Netherlands (2005) Cluster Weapons: Necessity or Convenience?. Report, June.<http://webcache.googleusercontent.com/search?q=cache:eeFwfXG39bMJ:www. paxforpeace.nl/media/files/cluster-weapons-necessity-orconvenience.pdf+\&cd=1\&hl=es\&ct=clnk\&gl=es> (Accessed 10 March 2015).

Payne, Rodger A. (2001) Persuasion, Frames and Norm Construction. European Journal of International Relations 37(1): 37-61.

Penketh, Anne. (2007) British U-turn Brings Global Ban on Deadly Cluster Bombs a Step Closer. Independent, February 24, p. 32 
Pratkanis, Anthony. (2000) Altercasting as an Influence Tactic. In Attitudes, Behavior and Social Context: The Role of Norms and Group Membership, eds. Deborah J. Terry and Michael A. Hogg, 201-226. Mahwah, NJ: Lawrence Erlbaum Associates, Inc.

Price, Richard. (1998) Reversing the Gun Sights: Transnational Civil Society Targets Landmines. International Organization 52(3): 613-644.

Price, Richard. (2008) Moral Limit and Possibility in World Politics. International Organization 62(2): 191-220.

Rappert, Brian (2005) Out of Balance. Landmine Action Report, Novermber. <https://ore.exeter.ac.uk/repository/bitstream/handle/10036/35217/Out_of_Balance.pdf ?sequence=1> (Accessed 11 March 2006).

Reh, Christine. (2011) Consensus, Compromise, and “Inclusive Agreement”. In Arguing Global Governance, eds. Corneliu Bjola and Markus Kornprobst, 177-192. London and New York: Routledge.

Riker, William H. (1986) The Art of Political Manipulation. New Haven and London: Yale University Press.

Riker, William H. (1996) The Strategy of Rhetoric: Campaigning for the American Constitution, Randall L. Calvert, John Mueller, and Rick K. Wilson, eds. New Haven and London: Yale University Press.

Risse, Thomas. (1999) International Norms and Domestic Change: Arguing and Communicative Behavior in the Human Rights Area. Politics and Society 27(4): 529-559.

Risse, Thomas. (2000) 'Let’s Argue': Communicative Action in World Politics. International Organization 54(1): 1-39. 
Risse, Thomas. (2004) Global Governance and Communicative Action. Government and Opposition 39(2): 288-313.

Risse, Thomas and Mareike Kleine. (2010) Deliberation in Negotiations. Journal of European Public Policy 17(5): 708-726.

Risse, Thomas and Kathryn Sikkink. (1999) The Socialization of Human Rights Norms into Domestic Practices: Introduction. In The Power of Human Rights: International Norms and Domestic Change, eds. Thomas Risse, Stephen C. Ropp, and Kathryn Sikkink, 1-38. Cambridge: Cambridge University Press.

Rorty, Richard. (2000) Universality and Truth. In Rorty and His Critics, ed. Robert B. Brandom, 1-30. Oxford: Blackwell.

Rutherford, Kenneth R. (2000) The Evolving Arms Control Agenda: Implications of the Role of NGOs in Banning Antipersonnel Landmines. World Politics 53(1): 74114.

Rutherford, Kenneth R. (2003) Post-Cold War Superpower? Mid-Size State and NGO Collaboration in Banning Landmines. In Reframing the Agenda: The Impact of NGO and Middle Power Cooperation in International Security Policy, eds. Kenneth R. Rutherford, Stefan Brem and Richard Matthew, 23-38. Westport, Conn: Praeger. Sasley, Brent E. (2011) Theorizing States’ Emotions. International Studies Review 13(3): 452-476.

Schimmelfennig, Frank. (2001) The Community Trap: Liberal Norms, Rhetorical Action, and the Eastern Enlargement of the European Union. International Organization 55(1): 47-80.

Schimmelfennig, Frank. (2003) The EU, NATO and the Integration of Europe: Rules and Rhetoric. Cambridge: Cambridge University Press. 
Steffek, Jens. (2005) Incomplete Agreements and the Limits of Persuasion in International Politics. Journal of International Relations and Development 8(3): 229256.

Taylor, Jerome. (2011) UK Backs Bid to Overturn Ban on Cluster Bombs.

Independent, November 9. < $\underline{\text { http://www.independent.co.uk/news/world/politics/uk- }}$ backs-bid-to-overturn-ban-on-cluster-bombs-6259139.html> (Accessed 12 May 2014).

Thomas, Daniel C. (2009) Explaining the Negotiation of EU Foreign Policy:

Normative Institutionalism and Alternative Approaches. International Politics 46(4): 339-357.

Turner, Monique Mitchel, John A. Banas, Stephen A. Rains, SuAhn Jang, Jessica L. Moore, and Dan Morrison. (2010) The Effects of Altercasting and Counterattitudinal Behavior on Compliance. Communication Reports 23(1): 1-13.

Ulbert, Cornelia and Thomas Risse. (2005) Deliberately Changing the Discourse: What Does Make Arguing Effective?. Acta Politica 40(3): 351-367.

UK Foreign and Commonwealth Office. (2009) Cluster Munitions Ban Will Make World a Safer Place, November 20.

<http://webarchive.nationalarchives.gov.uk/20121212135632/http://www.fco.gov.uk /resources/en/news/11646391/21103022/cluster-munitions-201109 > (Accessed 29 March 2015).

UK Foreign and Commonwealth Office. (2010) Cluster Bombs Banned by the UK, March 25.

<http://webarchive.nationalarchives.gov.uk/20100413151426/http://www.fco.gov.uk /en/news/latest-news/?view=News\&id=21956420 > (Accessed 29 March 2015). 
UK Government. (2007) Response of the Secretaries of State for Defence, Foreign and Commonwealth Affairs, International Development and Business, Enterprise and Regulatory Reform. Presented to Parliament, November.

<https://www.gov.uk/government/uploads/system/uploads/attachment_data/file/2431 49/7260.pdf $>$ (Accessed 10 August 2014).

UK House of Commons. (2006a) House of Commons Hansard Debates, November 22. <http://www.publications.parliament.uk/pa/cm200607/cmhansrd/cm061122/debtext/ 61122-0008.htm> (Accessed 11 February 2007).

UK House of Commons. (2006b) House of Commons Hansard Debates, November 23. <http://www.publications.parliament.uk/pa/cm200607/cmhansrd/cm061123/debtext/ 61123-0022.htm> (Accessed 11 February 2007).

UK House of Commons. (2011) House of Commons Hansard, November 9. < http://www.publications.parliament.uk/pa/cm201011/cmhansrd/cm111109/debtext/ 111109-0004.htm\#111109105000002> (Accessed 12 February 2012).

UK House of Lords. (2006) House of Lords Hansard, December 15.

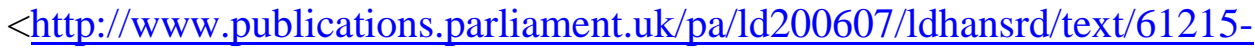
0004.htm>, $<\underline{\text { http://www.publications.parliament.uk/pa/ld200607/ldhansrd/text/61215- }}$ $\underline{\text { 0005.htm }}>$ (Accessed 11 February 2007).

UK House of Lords. (2011) House of Lords Hansard Questions, November 10. < http://www.publications.parliament.uk/pa/ld201011/ldhansrd/text/111110-

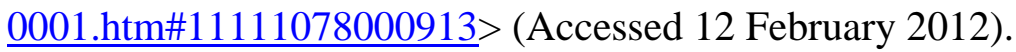

United Kingdom. (2005) Military Utility of Cluster Munitions. Working paper prepared by the UK, February 21. UN document CCW/GGE/X/WG.1/WP.1. 
United Kingdom. (2008) Statement on Article I: General Scope and Obligations. Wellington Conference on Cluster Munitions, February 18.

< $\underline{\text { http://web.archive.org/web/20100522165157/http://www.mfat.govt.nz/clustermunit }}$ ionswellington/conference-documents/UK-intervention.pdf> (Accessed 15 March 2015).

United Kingdom. (2015) United Kingdom of Great Britain and Northern Ireland High Level Segment - Opening Statement. Dubrovnik CCM Review Conference, September. https://www.clusterconvention.org/files/2015/09/UK_High-LevelSegment1.pdf

US Embassy Cables: Cluster Bomb Talks a Tactical Manoeuvre, UK Says (2010)

Guardian, December 1. < http://www.theguardian.com/world/us-embassy-cablesdocuments/208206> (Accessed 3 December 2010).

Weinstein, Eugene A. and Paul Deutschberger. (1963) Some Dimensions of Altercasting. Sociometry 26(4): 454-466.

Weinstein, Eugene A. and Paul Deutschberger. (1964) Tasks, Bargains, and Identities in Social Interaction. Social Forces 42(4): 451-456.

Wendt, Alexander. (1999) Social Theory of International Politics. Cambridge: Cambridge University Press.

Williams, Jody. (2008) Doing Their Dirty Work. Guardian, May 27. <http://www.theguardian.com/commentisfree/2008/may/27/military.armstrade> (Accessed 12 June 2008). 